\title{
ГІПОЛІПІДЕМІЧНІ ЛІКАРСЬКІ ЗАСОБИ ГРУПИ СТАТИНІВ В УКРАЇНІ: АНАЛІЗ АСОРТИМЕНТУ, ЕКОНОМІЧНӦ̈ ДОСТУПНОСТІ ТА ОБ'ЄМІВ СПОЖИВАННЯ
}

\author{
Шуляк Л. М., Бердник О. Г.
}

\section{ВСТУП}

Станом на сьогодні серцево-судинні захворювання (СС3) залишаються однією 3 головних причин смертності в усьому світі. За даними Всесвітньої організації охорони здоров'я ${ }^{1}$, щорічно від кардіоваскулярної патології гинуть у середньому більш ніж 17 млн осіб населення земної кулі. Так, у розвинених країнах світу показники летальності від серцевосудинних хвороб знижуються, тоді як у країнах 3 низьким рівнем економічного розвитку - стрімко зростають. Україна входить у другу групу країн ${ }^{2}$. Дисліпідемія - одна 3 основних причин розвитку атеросклерозу та ішемічної хвороби серця (IXC), що з часом призводять до інвалідизації та підвищують ризик ранньої смерті у всьому світі ${ }^{3}$. Натепер встановлено прямий кореляційний зв'язок між захворюваністю і летальністю від серцево-судинних захворювань (СС3), з одного боку, і рівнем загального холестерину (3ХC) в крові, ХС ліпопротеїнів низької щільності (ЛПНЩ) 3 іншого. Своєю чергою гіперхолестеринемія, поряд із палінням, ожирінням, артеріальною гіпертензією, цукровим діабетом (ЦД) і віком, визначена головним предиктором розвитку атеросклерозу і його ускладнень ${ }^{4}$.

${ }^{1}$ Европейский региональный комитет. 61-я сессия ВОЗ. Баку, 12-15 сент. 2011 г. План действий по Европейской стратегии профилактики и борьбы с неинфекционными заболеваниями, 2012-2016 гг. ВОЗ, 2011. С. 2-5.

2 Трагедія, якої можна уникнути: Подолання в Україні кризи здоров'я людини. Досвід Свропи. Світовий Банк. Київ, 2009. 72 с.

3 Трагедія, якої можна уникнути: Подолання в Україні кризи здоров'я людини. Досвід Європи. Світовий Банк. Київ, 2009. 72 с.; Бронцель М. Розувастатин на фоне других статинов. Польща: Клиника (кафедра) внутренних болезней и клинической фармакологии Медицинского университета в г. Лодзь, 2011. 7 с.

${ }^{4}$ Бронцель М. Розувастатин на фоне других статинов. Польща: Клиника (кафедра) внутренних болезней и клинической фармакологии Медицинского университета в г. Лодзь, 2011. 7 с.; Серцево-судинні захворювання в Україні: прогнози - невтішні. Всеукраӥнська медична газета “Ваше здоров'я”. 2015. URL: https://www.vz.kiev.ua/sercevo-sudinni-zaxvoryuvannya-v-ukrayini-prognozi-nevtishni/ (дата звернення: 20.01.2020); Мурашко Н.К., Матяш М.М., Парнікоза Т.П. та ін. Дисліпопротеінемії в неврологічній практиці : навч.-метод. рекомендації. Київ : Міністерство охорони здоров'я України, 2013. 
Роль дисліпідемії в розвитку та прогресуванні СС3 в наш час не підлягає сумніву та має під собою суттєве підгрунтя для подальшого дослідження цієї проблеми як для всього населення планети, так і для окремого громадянина своєї країни. В епідеміологічних дослідженнях встановлено, що підвищення рівнів холестерину ліпопротеїнів низької щільності (ХС ЛПНЩ), тригліцеридів, холестерину ліпопротеїнів дуже низької щільності та зниження концентрації ліпопротеїнів високої щільності (ХС ЛПВЩ) є одними з найважливіших факторів ризику СС3 ${ }^{5}$.

Статини займають стабільне положення в кардіології і донині залишаються найбільш розповсюдженим класом лікарських препаратів, що застосовуються для лікування гіперхолестеринемії. Зокрема, в наш час вони складають основу терапії, спрямованої на зниження ризику серцево-судинних ускладнень, пов'язаних 3 атеросклерозом. Ці препарати рекомендуються пацієнтам зі стабільною IXC, у разі гострого коронарного синдрому, після інсультів, під час захворювань периферичних судин та ЦД 6 .

За механізмом дії гіполіпідемічні засоби групи статинів належать до інгібіторів ГМГ-КоА-редуктази - ферменту, який визначає швидкість синтезу ХС в клітині, перетворюючи 3-гідрокси-3-метилглютарилкоензим А на мевалонову кислоту. В результаті пригнічення ГМГ-КоАредуктази знижується внутрішньоклітинний вміст ХС та збільшується експресія рецепторів до ХСЛНЩ, вміст ХСЛНЩ в крові, відповідно, знижується ${ }^{7}$.

Ефективність статинів у відношенні зниження смертності від СС3, а саме від серцево-судинних випадків (інфаркт міокарда, мозковий інсульт та ін.) вважається абсолютно доказаною. Так, результати досліджень 4S, LIPID, AFCAPS/TexCAPS переконливо підтвердили ефективність статинів у корекції дисліпідемій. Сприятливий вплив статинів на клінічні кінцеві точки встановлено як у хворих на IXC (4S, LIPID, CARE), так і у осіб без ознак цього захворювання

${ }^{5}$ Долженко М.М., Базілевич А.Я., Сімагіна Т.В. Застосування статинів у хворих на IXC. Київ : НМАПО ім.П.Л. Шупика спільно з ЛМДУ ім.Данило Галицького, 2011. 8 c.

${ }^{6}$ Nissen S. E., Tuzcu E., Schoenhagen P. et al.; REVERSAL Investigators. Statin therapy, LDL cholesterol, C-reactive protein, and coronary artery disease. N. Engl. J. Med. 2005. Vol. 352. P. 29-38.

7 Трагедія, якої можна уникнути: Подолання в Україні кризи здоров'я людини. Досвід Європи. Світовий Банк. К., 2009. 72 с.; Бронцель М. Розувастатин на фоне других статинов. Польща : Клиника (кафедра) внутренних болезней и клинической фармакологии Медицинского университета в г. Лодзь, 2011. 7 с. 
(WOSCOPS, AFCAPS/TexCAPS), причому не тільки у разі вираженої гіперхолестеринемії, але й за відносно невисокого рівня ХС ЛПНЩ ${ }^{8}$.

Метою досліджень стало формування сучасного клінічного погляду на наявний досвід застосування та подальші перспективи розвитку фармацевтичного ринку гіполіпідемічних лікарських засобів (ГЛЗ), що спостерігались протягом 2015-2018 pp.

\section{1. Аналіз асортименту препаратів групи інгібіторів ГМГ-КоА-редуктази для корекції дисліпідемій на фармацевтичному ринку України}

На цей час у терапевтичній кардіологічній практиці є 7 МНН статинів, що відрізняються один від одного за хімічною структурою, фармакокінетичними властивостями та виразністю гіполіпідемічної дії.

\section{1. Монокомпонентні гіполіпідемічні препарати}

Згідно з міжнародною АТС-класифікацією монокомпонентні ГЛЗ групи інгібіторів ГМГ-КоА-редуктази можна віднести до класифікатора C10A. Особливості фармакокінетики ГЛЗ припускають застосування в клінічній практиці лише таблетованих форм ЛЗ. Передусім це пов'язано з високим ступенем зв'язування препаратів цієї групи з білками плазми крові та високою біодоступністю препаратів. За підсумками проведеного дослідження та згідно з даними інформаційнопошукової системи Моріон, було встановлено, що на фармацевтичному ринку України станом на 2018 рік було зареєстровано 185 ТН, на основі 5 МНН. Широкий асортимент ГЛЗ налічував біля 21\% препаратів вітчизняного виробництва та 79\% - іноземного.

Головні лідерські місця серед закордонних виробників посіли Словенія (30 TH - 16\%), Індія (27 TH - 14,8\%), Франція (17 TH - 9\%), Ізраїль (16 TH - 8,6\%), США (15 ТН - 8\%), Швейцарія (13 ТН - 7\%) тощо. Всі інші виробники імпортували менше 5\% від загальної кількості. До них можна віднести: Польщу - 3,8\%, Угорщину, Македонію та Італію - по 2,7\%, Великобританію - 2,2\%, Кіпр та Турцію - по 1\%.

Деякі країни взагалі представили на фармацевтичному ринку України лише 1 ТН. Наприклад, оригінальний препарат розувастатину - КРЕСТОР®, Astra-Zeneca (Великобританія), табл. вкр./плів. оболонкою в дозуванні 5, 10, 20 та 40 мг, чи оригінальний ГЛЗ 3

${ }^{8}$ Banach M., Jankowski P., Jóźwiak J. et al. PoLA/CFPiP/PCS Guidelines for the Management of Dyslipidaemias for Family Physicians. Arch. Med. Sci. 2016. 13(1). P. $1-45$.

${ }^{9}$ Nissen S. E., Tuzcu E., Schoenhagen P. et al.; REVERSAL Investigators. Statin therapy, LDL cholesterol, C-reactive protein, and coronary artery disease. N. Engl. J. Med. 2005. Vol. 352. P. 29-38. 
підгрупи пітавастатину - ЛІВАЗО, Recordati Group (Італія), табл. вкр./плів. оболонкою по 1,2 та 4 мг. Передусім це можна пояснити тим, що ЛІВАЗО належить до статинів IV покоління, які порівняно недавно 3'явились на фармацевтичному ринку України, мають патентний захист на 20 років та не мають генеричних аналогів, доступних за ціною. Клінічні фармакоепідеміологічні дослідження ефективності та безпечності пітавастатину ще досі тривають у різних країнах світу ${ }^{10}$.

Загалом протягом досліджуваного періоду спостерігалось стрімке зростання ТН. Якщо в 2015 р. налічувалось лише 173, то в 2018 їх кількість зросла до $183 \mathrm{TH}$ У У 2018 році з ринку статинів пішов єдиний препарат МНН C10А А04 Флувастатину - ЛЕСКОЛ® XL, Novartis Pharma (Швейцарія), табл. п/о 80 мг, № 28, і асортимент статинів на фармацевтичному ринку України зменшився до 5 МНН. Вилучення 3 обігу аптек та клінічної практики лікарів Лесколу можна пояснити досить обмеженим призначенням та застосуванням, недостатнім об'ємом даних щодо клінічних досліджень та низькою ефективністю відносно інших більш вживаних статинів на території України.

Протягом чотирьох досліджуваних років найбільшою кількістю торгових найменувань серед інгібіторів ГМГ-КоА-редуктази ФР України був забезпечений препаратами 3 МHН С10А A05 Аторвастатину: ТН варіювались від 79 до 81. Причому з кожним роком кількість не стрімко, проте зменшувалась, що могло бути пов'язано 3 ребрендингом, цілеспрямованим уведенням виробниками нових ГЛЗ в менших дозуваннях, проте більш ефективних препаратів, що позитивно впливає на організм людини.

Аторвастатин - препарат III покоління, що справляє досить сильний гіполіпідемічний ефект, особливо у хворих з резистентністю до інших ГЛЗ та зі спадковою гіперхолестеринемією. За рахунок ряду своїх плейотропних властивостей препарат зменшує запалення, викликає регресію атеросклеротичних бляшок та знижує ризик повторних ішемічних нападів у хворих з нестабільною стенокардією та інфарктом міокарда. Про те, що аторвастатин є одним із добре вивчених на цей час статинів, свідчать результати багаточисельних рандомізованих досліджень, ретроспективних аналізів, баз даних пацієнтів та метааналізу, і щодо цього немає жодного сумніву ${ }^{11}$. Доказом того може

10 Яковлєва Л.В., Бездітко Н.В., Герасимова О.О. Фармакоекономіка : навч. посібник для студентів вузів. Вінниця : Нова Книга, 2009. 208 с.

11 Сусеков А.В., Хохлова Н.В. ЛИПРИМАР®. Пятнадцать лет убедительных доказательств. Рациональная Фармакотерапия в Кардиологии. 2011. № 7. С. 231-240.; Гоголашвили Н. В. Аторвастатин - 20 лет в борьбе за жизнь. Российский кардиологический журнал. 2018. № 2. С. 134-149; Аторвастатин: классические 
служити оригінальний новітній препарат - ЛІПРИМАР®, Pfizer Inc. (США), в дозуванні 10, 20, 40 та 80 мг ${ }^{12}$ - найбільш відоме брендове “обличчя" аторвастатину. Окрім того, що ЛІПРИМАР ${ }^{\circledR}$ - сучасний синтетичний інгібітор ГМГ-КоА-редуктази, він також найбільш призначуваний статин у світі, добре вивчений у клінічних дослідженнях у найрізноманітніших популяцій хворих (первинна та вторинна профілактика, особи високого СС ризику з ЦД2Т, АГ, після перенесеного інсульту/транзиторно-ішемічної атаки (ТIA), зі стабільною IXC тощо). Протягом 2015-2018 років на ФР України ЛІПРИМАР® був найдорожчим препаратом як у межах підгрупи аторвастатину, так i серед всього зареєстрованого асортименту статинів, представлених на цей час. Вартість препарату коливалась (дешевшала) з 2015 р. - 2 872,11 грн до 1040,95 грн у 2018 році.

Підгрупа розувастатину С10A А07 протягом досліджуваного періоду за чисельністю торгових найменувань не поступалась аторвастатину, проте й мала свої переваги на ринку України. 3 кожним роком вибір розувастатину для українців розширювався за рахунок нових генериків: 355 ТН у 2015 р. до 77 - у 2018 р. (таке ж число ТН було притаманне аторвастатину два роки поспіль, станом на 2016-201 pр.). На цей момент розувастатин $\epsilon$ найефективнішим статином у зниженні рівнів ЗХС та ХС ЛПНЩ, а також в підвищенні рівня "захисного" ХС ЛПВЩ, що було показано в дослідженні STELLAR $^{7}$, в якому порівнювали ефект різних доз розувастатину, аторвастатину, симвастатину та правастатину на ліпідний профіль хворих на гіперліпідемію. Застосування розувастатину дозволило досягнути цільового рівня ХС ЛПНЩ у більшості пацієнтів порівняно 3 іншими статинами. Існуючі переваги розувастатину, скоріш за все, асоційовані з його здатністю більшою мірою взаємодіяти с ГМГ-КоАредуктазою, що пов'язано з більш високою спорідненістю до активного центру цього ензиму ${ }^{13}$.

исследования и их современная интерпретация. Доказательная база аторвастатина для практического врача. Атмосфера. Новости кардиологии. 2015. № 2. С. 26-30; Агеев Ф.Т. Аторвастатин: классические исследования и их современная интерпретация. Доказательная база аторвастатина для практического врача. Атмосфера. Новости кардиологии. 2015. № 2. С. 26-30; Пузік С.Г. Статини у профілактиці цереброваскулярних хвороб при арте-ріальній гіпертензії. У фокусі аторвастатин. Семейная медицина. 2015. № 3. С. 110-111.

${ }^{12}$ Cholesterol Treatment Trialists (CTT) Collaboration. The effects of lowering LDL cholesterol with statin therapy in people at low risk of vascular disease: meta-analysis of individual data from 27 randomised trials. Lancet. 2012. Vol. 378.

13 Березин А.Е. Роль статинов в современной стратегии лечения кардиоваскулярных заболеваний: фокус на аторвастатин. Український медичний часопис. 2017. № 2. С. 89-93. 
Розувастатин відносять до інгібіторів ГМГ-КоА-редуктази нового покоління 3 унікальними фармакокінетичними та фармакодинамічними властивостями. Його гідрофільна структура забезпечує високоселективну та тривалу взаємодію з ГМГ-КоАредуктазою гепатоцитів. Гіполіпідемічна активність препарату досягається мінімальними дозами, що підтверджено експериментально. Крім того, клінічні результати доводять, що розувастатин у дозі 10-80 мг виявляє більшу ефективність порівняно з еквівалентними дозами інших інгібіторів синтезу ХС. Низький рівень метаболічної взаємодії робить його препаратом вибору для включення в багатокомпонентні схеми лікування 3 коморбідною патологією. Варто зазначити, що особливістю розувастатину $\epsilon$ його системна протизапальна активність як складник комплексної фармакотерапії різних варіантів дисліпідемій. Перевагою лікарського засобу також $є$ висока безпека, оскільки індекс проникнення в позапечінкові тканини мінімальний ${ }^{14}$.

Симвастатин - один із найбільш часто призначуваних ефективних, безпечних та доступних статинів на ринку України. Численні багатоцентрові клінічні дослідження відповідно до суворих сучасних стандартів довели ефективність симвастатину не тільки під час вторинної профілактики СС3, але й у пацієнтів з цукровим діабетом, а також у осіб с дисліпідемією. Існують вагомі підстави стверджувати про значний вплив статинів на ланки патогенезу деяких ревматичних захворювань. Хоча симвастатин - не перший синтезований статин, найбільш грунтовні докази ефективності цієї фармакологічної групи у відношенні клінічно значущих наслідків серцево-судинних хвороб були отримані саме 3 застосуванням цього препарату. 3 часом результати практично всіх досліджень симвастатину радикально змінювали сучасну кардіологічну практику та за допомогою доказів затверджували показання до застосування цього препарату у разі нових захворювань та синдромів. Нещодавній ретроспективний популяційний фармакоекономічний аналіз показав, що терапія симвастатином достовірно знижує витрати на госпіталізацію та втручання з приводу будь-яких серцево-судинних ускладнень.

14 Reiner Z., Catapano A. L., De Backer G. et al. ESC/EAS Guidelines for the management of dyslipidaemias: the Task Force for the management of dyslipi-daemias of the European Society of Cardiology (ESC) and the European Athero-sclerosis Society (EAS). Eur Heart J. 2011. Vol. 32. P. 1769-1818. 


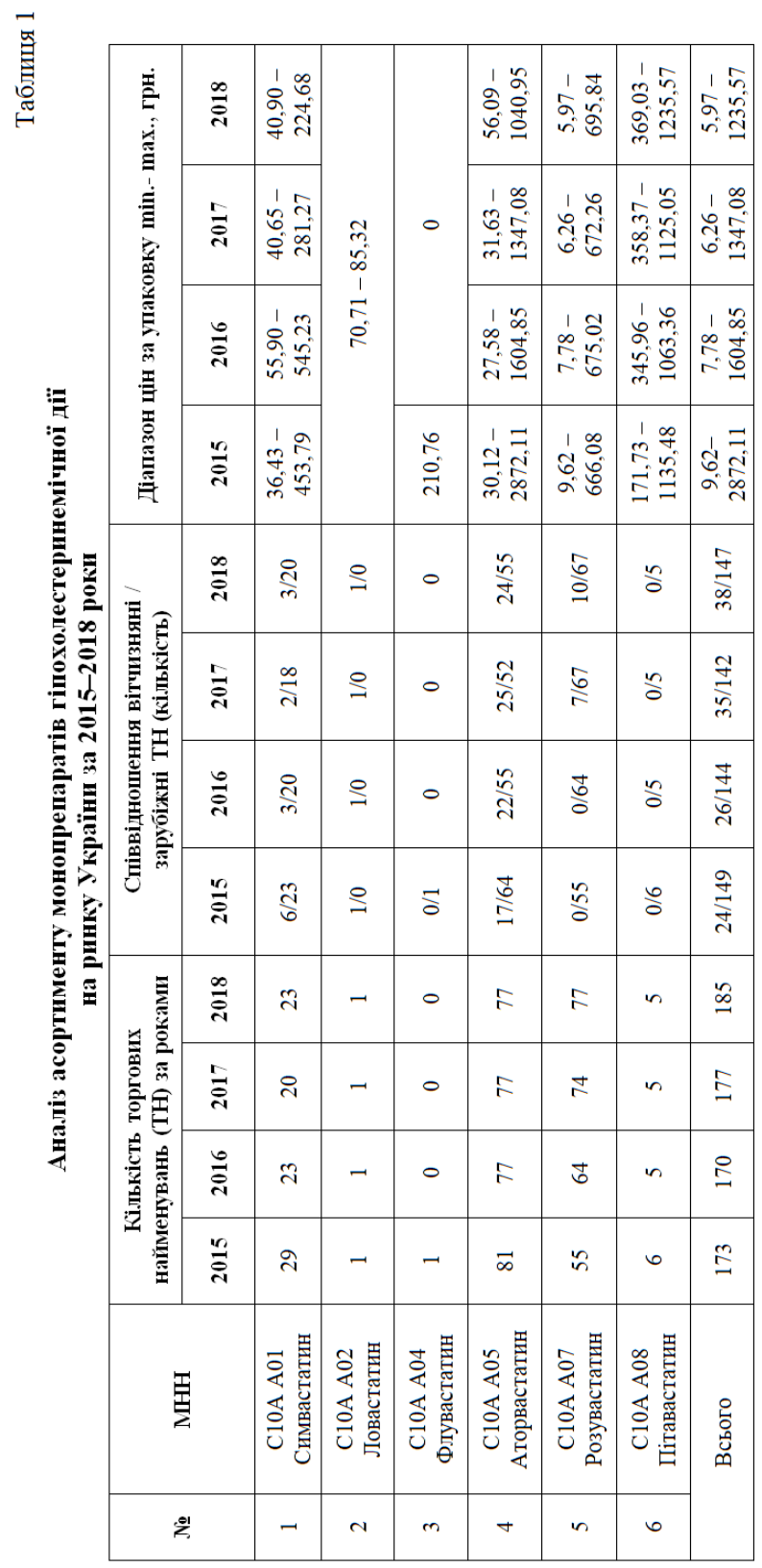


Класичним представником підгрупи симвастатину є оригінальний препарат з ТН ЗОКОР®, для якого вперше були отримані незаперечні докази щодо впливу на частоту розвитку тяжких серцево-судинних станів (інсультів і інфарктів) у пацієнтів з ССЗ. ЗОКОР ${ }$ надає виражену гіполіпідемічну дію, сповільнюе прогресування атеросклерозу, покращує прогноз IXC навіть у хворих з вихідними нормальними показниками ліпідного спектру. До безсумнівних переваг Зокора ${ }^{\circledR}$, як оригінального Л3, належить його висока ефективність, безпека, доступність, оптимальне співвідношення ціна / якість. Все це робить ЗОКОР $®$ засобом першої лінії в лікуванні атеросклерозу та IXC ${ }^{15}$.

Асортимент решти препаратів 3 групи інгібіторів ГМГ-КоАредуктази I та II поколінь був представлений досить обмежено. Це стосується ловастатину, котрий чотири роки поспіль був представлений лише єдиною ТН українського виробника - ЛОВАСТАТИН, Артеріум Корпорація ВАТ (Україна, Київ), табл. 20 мг блістер, № 30.

Через незацікавленість виробниками в “просуванні" та розширенні асортименту флувастатину на ринку України в 2015 р. його було вилучено 3 загального фармацевтичного обігу як недостатньо ефективний та безпечний препарат порівняно з аторва- та розувастатином, котрі на цей час більш поширені в призначеннях лікарів.

Діапазон цін на монокомпонентні ГЛЗ протягом 2015-2018 pp. варіював від 5,97 до 2 872,11 грн. Це давало змогу пацієнтам не лише обрати доступний за вартістю препарат згідно 3 фінансовими можливостями, а й досягнути позитивної динаміки та значних результатів у лікуванні та поліпшенні загальної клінічної картини власної серцево-судинної хвороби (табл. 4).

Найбільш доступним та дешевшим у 2018 р. виявився КЛІВАС 10, Аcino (Швейцарія), табл. вкр./плів. оболонкою 10 мг блістер, №10, а найбільш дороговартісним ЛЗ за всі чотири роки - брендовий ЛЗ ЛІПРИМАР®, Pfizer Inc. (США), табл. вкр./плів. оболонкою 20 мг блістер, № 100.

Структурний аналіз асортименту ГЛЗ 2018 року показав, що найбільший асортимент за ТН був притаманний для МНH: C10A A05 Аторвастатин та C10A A07 Розувастатин, в обох підгрупах нараховувалось по $77 \mathrm{TH}$ (табл. 1). Варто відмітити, що протягом досліджуваного періоду фармацевтичний ринок монокомпонентних ГЛЗ був досить нестабільним. Спостерігалась як поява нових, раніше невідомих генеричних ТН, так і вилучення вже добре відомих

15 Rubba P., Marotta G., Gentile M. Efficacy and safety of rosuvastatin in the management of dyslipidemia. Vasc. Health Risk Manag. 2009. 5(1). P. 343-352. 
генериків. Також деякі ГЛЗ проходили процес перереєстрації, у зв'язку з чим, згідно з даними компанії “Моріон”, цінові показники різко змінювались від високих до малих. Чимало ТН препаратів 3 підгруп аторва- та розувастатину пішли з фармацевтичного ринку як малодоступні для українського споживача: наприклад, РО-ВІКС, Apotex (Канада); ТУЛІП®, Sandoz (Швейцарія); ТОРЗАКС®, Alkaloid (Македонія); АТОТЕКС, Аpotex (Канада); АМВАСТАН, Rotapharm (Великобританія); СІМГАЛ, Теva (Ізраїль); СИМВАСТАТ, Stada (Німеччина); СИМ-ВАКАРД, Sanofi (Франція) та деякі дозування інші ЛЗ.

\section{2. Комбіновані гіполіпідемічні лікарські засоби (КГЛЗ)}

Аналіз асортименту КГЛЗ на фармацевтичному ринку України в 2018 р. зафіксував 5 комбінацій на основі 6 представлених МНH. Протягом досліджуваного періоду, як i в ситуації 3 монокомпонентними препаратами, на фармацевтичному ринку України відбулись як приріст нових, більш сучасних, так і скорочення кількості вже досить відомих ЛЗ першого покоління. Насамперед це може бути пов'язано з появою та виходом на світовий фармацевтичний ринок новітніх активних речовин в пролонгованих формах випуску, більш безпечних та доцільних 3 погляду ефективності комбінацій, що пройшли всі необхідні етапи клінічних досліджень. Дивлячись на представлені комбінації, можна зробити висновок, що в наш час зникла потреба в роздільному прийомі декількох окремих ліків 3 різних фармакологічних груп. Оскільки це не тільки значні економічні втрати в соціальному бюджеті пацієнтів, а й незручність прийому, недотримання комплаєнсу, підвищення ризику небажаних побічних ефектів, з якими може зіткнутись будь-хто з нас.

Оскільки КГЛЗ були представлені в меншій кількості, ніж монокомпонентні, відповідно, й налічували меншу кількість іноземних та вітчизняних виробників з різних кутків світу. В 2015 році була наявна найбільша кількість ТН КГЛЗ на фармацевтичному ринку України - 15 найменувань ЛЗ. Серед них виробництво США налічувало $6 \mathrm{TH}$ (40\% від усіх гіполіпідемічних комбінацій), в числі двох торгових назв, відповідно, під двома різними МНH - C10B А02 Симвастатин + езетиміб (TH IHЕДЖІ, MSD) та C10B X03 Аторвастатин + амлодипін (ТН КАДУЕТ, Pfizer Inc). На другому місці знаходяться Словенія та Угорщина з 4 ТН (відповідно 40\% у 2018 р. та $36,4 \%$ у 2016 р) (табл. 2). 


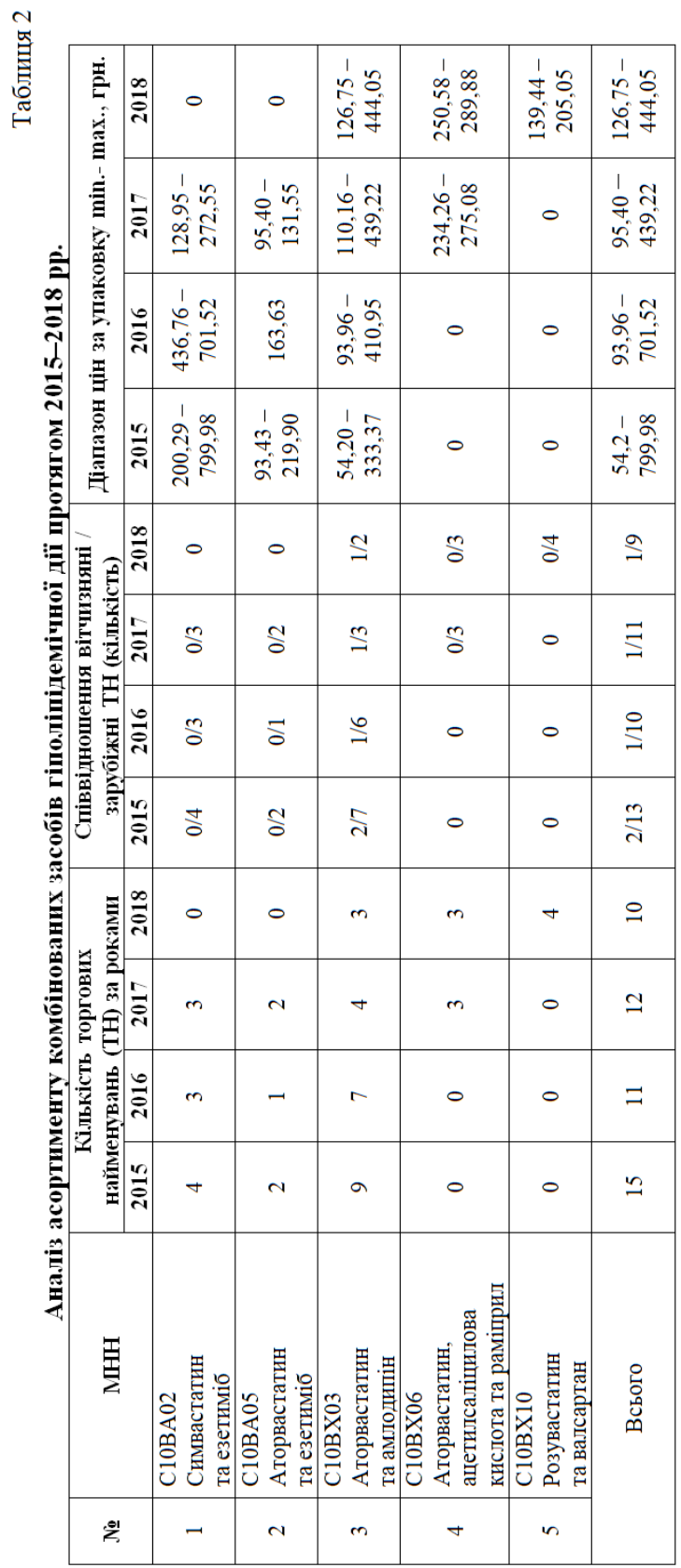


Словенія в різних дозуваннях була представлена лише однією комбінацією 3 групи С10В Х10 Розувастатин + валсартан під ТН ВАЛАРОКС, права власності на яку цілком належали фармацевтичній компанії KRKА. Однак препарат з'явився не так давно, в 2018 році, та вже зміг себе зарекомендувати в лікарняній практиці серед лікарів-кардіологів.

Препарат з підгрупи С10B Х03 Аторвастатин + амлодипін під ТН ДУПЛЕКОР® від виробника Gedeon Richter (Угорщина) пішов 3 фармацевтичного ринку через можливу причину неприбутковості та незначного споживання в Україні ще в 2016 році.

У 2017 році на фармацевтичному ринку з'явилась нова цікава комбінація ГЛЗ. Вона привернула увагу тим, що поєднувала в собі аж три активних інгредієнти, прийом яких раніше був можливий лише окремо. Вихід було знайдено японськими дослідниками, які запатентували нову комбінацію під ТН ТРИНОМІЯ у трьох різних дозуваннях (в 2017 р. $3 \mathrm{TH}-25 \%$ усього ринку комбінованих статинів). До складу лише однієї таблетки увійшло 3 субстанції лікарських речових, фармакологічна дія кожної з яких спрямована саме на усунення певної СС патології. Добре відомий серед гіполіпідемічних засобів - аторвастатин сприяє зниженню вмісту холестерину в сироватці крові, ацетилсаліцилова кислота розріджує кров 3 метою запобігання утворенню тромбофлебітів, раміприл - інгібітор ангіотензинперетворюючого ферменту, його використання викликає помітне зниження периферичного тиску у пацієнтів, хворих на гіпертонічну хворобу, та у якості комбінованої терапії під час спільного прийому разом 3 діуретиками та серцевими глікозидами в боротьбі з ХCH.

Четверте місце зайняв вітчизняний виробник з двома ТН на основі МНН С10В Х03 Аторвастатин + амлодипін - ТН АМЛОСТАТ (13,33\% в 2015 p.).

Діапазон цін на КГЛЗ складав 54,2 - 799,98 грн. Ціни виявились найвищими у 2015 році.

Станом на кінець 2018 року більшість комбінацій ГЛЗ не витримали потужної конкуренції на фармацевтичному ринку України, у зв'язку з чим були вилучені. Зокрема, Л3 з підгруп С10В А05 Аторвастатин + езетиміб та С10B А02 Симвастатин + езетиміб.

\section{2. Аналіз доступності та споживання статинів в Україні протягом 2015-2018 pp.}

\section{1. Аналіз соціально-економічної доступності статинів за показником Ca.s}

Для аналізу соціально-економічної доступності монопрепаратів та комбінованих засобів групи статинів розраховували показник адекватності 
платоспроможності (Ca.s), який показував частку заробітної плати, що витрачалась на придбання однієї упаковки ЛЗ. Було встановлено, що лікарські препарати 3 розрахунку вартості за упаковку можна було розділити на низько- $(\geq 5 \%)$, середньо- $(5 \%<$ Ca.s. $\leq 15 \%)$ та високодоступні ГЛЗ (<15\%). Отримані результати у відсотковому співвідношенні кількості ТН за певним значенням Ca.s відповідно до кожного МНН подано у табл. 3. Загальна кількість торгових найменувань по кожному МНН на фармацевтичному ринку протягом кожного досліджуваного року була прийнята за $100 \%{ }^{16}$.

За підсумками аналізу результатів було встановлено, що більшість гіполіпідемічних препаратів була представлена високодоступними ЛЗ. Однак були й ті, що входили до категорії середньо- (МНН Симвастатин, Аторвастатин, Розувастатин та Пітавастатин) та низькодоступних (МНН Розувастатин, Аторвастатин та Пітавастатин).

Таблиця 3

\section{Аналіз доступності монопрепаратів групи статинів за показником Ca.s.}

\begin{tabular}{|c|c|c|c|c|c|}
\hline \multirow{2}{*}{$\begin{array}{c}\text { АТС - код, } \\
\text { МНН } \\
\text { препарату }\end{array}$} & \multirow{2}{*}{ Категорія ЛЗ } & \multicolumn{4}{|c|}{$\begin{array}{l}\text { Кількість ТН ЛЗ у\% } \\
\text { (абсолютна величина) }\end{array}$} \\
\hline & & 2015 p. & $2016 \mathrm{p}$. & 2017 p. & 2018 p. \\
\hline \multirow{3}{*}{$\begin{array}{c}\text { C10A А01 } \\
\text { Симвастатин }\end{array}$} & Високодоступні & $\begin{array}{l}82,76 \\
(24 \mathrm{TH}) \\
\end{array}$ & $\begin{array}{c}86,96 \\
(20 \mathrm{TH}) \\
\end{array}$ & $\begin{array}{c}100 \\
(20 \mathrm{TH})\end{array}$ & $\begin{array}{c}100 \\
(23 \mathrm{TH})\end{array}$ \\
\hline & Середньодоступні & $\begin{array}{l}17,24 \\
(5 \mathrm{TH}) \\
\end{array}$ & $\begin{array}{l}13,04 \\
(3 \mathrm{TH}) \\
\end{array}$ & - & - \\
\hline & Низькодоступні & - & - & - & - \\
\hline \multirow{3}{*}{$\begin{array}{l}\text { C10А А02 } \\
\text { Ловастатин }\end{array}$} & Високодоступні & $100(1 \mathrm{TH})$ & $100(1 \mathrm{TH})$ & $100(1 \mathrm{TH})$ & $100(1 \mathrm{TH})$ \\
\hline & Середньодоступні & - & - & - & - \\
\hline & Низькодоступні & - & - & - & - \\
\hline \multirow{3}{*}{$\begin{array}{c}\text { C10А А04 } \\
\text { Флувастатин }\end{array}$} & Високодоступні & - & - & - & - \\
\hline & Середньодоступні & $100(1 \mathrm{TH})$ & - & - & - \\
\hline & Низькодоступні & - & - & - & - \\
\hline
\end{tabular}

16 Думенко Т.М., Парій В.Д., Яковлєва Л.В., Зіменковський А.Б. Вивчення доступності основних лікарських засобів в Україні: результати спільного проекту BOO3, НAI та MO3 Україні. Фармакоекономіка в Украӥні: стан та перспективи розвитку: матер. VI наук.-практ. конф. (Харків, 22 листопада 2013 р.). Х.: НФаУ, 2013. C. $180-281$. 
Закінчення таблиці 3

\begin{tabular}{|c|c|c|c|c|c|}
\hline \multirow{2}{*}{$\begin{array}{c}\text { АТС - код, } \\
\text { МНН } \\
\text { препарату }\end{array}$} & \multirow{2}{*}{ Категорія ЛЗ } & \multicolumn{4}{|c|}{$\begin{array}{c}\text { Кількість ТН ЛЗ у\% } \\
\text { (абсолютна величина) }\end{array}$} \\
\hline & & $2015 \mathrm{p}$. & 2016 p. & 2017 p. & $2018 \mathrm{p}$. \\
\hline \multirow{3}{*}{$\begin{array}{c}\text { C10А А05 } \\
\text { Аторвастатин }\end{array}$} & Високодоступні & $\begin{array}{c}66,67 \\
(54 \mathrm{TH})\end{array}$ & $\begin{array}{c}77,92 \\
(60 \mathrm{TH})\end{array}$ & $\begin{array}{c}84,41 \\
(65 \mathrm{TH})\end{array}$ & $\begin{array}{c}89,87 \\
(71 \mathrm{TH})\end{array}$ \\
\hline & Середньодоступні & $\begin{array}{c}25,93 \\
(21 \mathrm{TH})\end{array}$ & $\begin{array}{c}14,29 \\
(11 \mathrm{TH})\end{array}$ & $\begin{array}{l}11,69 \\
(9 \mathrm{TH})\end{array}$ & $\begin{array}{c}10,13 \\
(8 \mathrm{TH})\end{array}$ \\
\hline & Низькодоступні & 7,4 (6TH) & $\begin{array}{c}7,79 \\
(6 \mathrm{TH})\end{array}$ & $\begin{array}{c}3,9 \\
(3 \mathrm{TH})\end{array}$ & - \\
\hline \multirow{3}{*}{$\begin{array}{c}\text { C10A А07 } \\
\text { Розувастатин }\end{array}$} & Високодоступні & $\begin{array}{c}61,82 \\
(34 \mathrm{TH}) \\
\end{array}$ & $\begin{array}{c}78,13 \\
(50 \mathrm{TH}) \\
\end{array}$ & $\begin{array}{c}90,54 \\
(67 \mathrm{TH}) \\
\end{array}$ & $\begin{array}{c}92,21 \\
(71 \mathrm{TH}) \\
\end{array}$ \\
\hline & Середньодоступні & $\begin{array}{c}36,36 \\
(20 \mathrm{TH}) \\
\end{array}$ & $\begin{array}{c}21,87 \\
(14 \mathrm{TH}) \\
\end{array}$ & $\begin{array}{c}9,46 \\
(7 \mathrm{TH}) \\
\end{array}$ & $\begin{array}{c}7,79 \\
(6 \mathrm{TH}) \\
\end{array}$ \\
\hline & Низькодоступні & $\begin{array}{c}1,82(1 \\
\mathrm{TH})\end{array}$ & - & - & - \\
\hline \multirow{3}{*}{$\begin{array}{c}\text { C10A A08 } \\
\text { Пітавастатин }\end{array}$} & Високодоступні & $\begin{array}{l}16,67 \\
(1 \mathrm{TH})\end{array}$ & - & - & $\begin{array}{c}20 \\
(1 \mathrm{TH}) \\
\end{array}$ \\
\hline & Середньодоступні & $\begin{array}{c}66,66 \\
(4 \mathrm{TH}) \\
\end{array}$ & $80(4 \mathrm{TH})$ & $80(4 \mathrm{TH})$ & $\begin{array}{c}80 \\
(4 \mathrm{TH}) \\
\end{array}$ \\
\hline & Низькодоступні & $\begin{array}{r}16,67 \\
(1 \mathrm{TH}) \\
\end{array}$ & $20(1 \mathrm{TH})$ & $20(1 \mathrm{TH})$ & - \\
\hline
\end{tabular}

Препарати МНН симвастатину на українському фармацевтичному ринку в 2015 та 2016 р. були представлені високодоступними ЛЗ в числі 24 та 20 ТН, що складало 82,76\% та 86,96\% відповідно. Своєю чергою до середньодоступних були віднесені 5 ТН в 2015 р. $(17,24 \%)$ та 3 ТН в 2016 р. (біля 13\%). Низькодоступних ЛЗ виявлено не було.

МНН ловастатину протягом чотирьох досліджуваних років налічувало лише $1 \mathrm{TH}$, яка всі роки було високодоступною.

Серед монопрепаратів ГЛЗ аторвастатину в 2015 році високодоступними були 54 ТН $(66,67 \%)$, середньодоступними - $21 \mathrm{TH}$ $(25,93 \%)$, і $6 \mathrm{TH}(7,4 \%)$ були віднесені до низькодоступних на базі оригінального ЛЗ - ЛІПРИМАР®.

У наступному 2016 р. до категорії високодоступних війшли вже $60 \mathrm{TH}(77,92 \%)$, до середньодоступних - $11 \mathrm{TH}(14,29 \%)$ i до низькодоступних - ті ж самі $6 \mathrm{TH}$, проте в трохи більшій частці 7,79\%. У 2017 році загальна кількість ТН не змінилась порівняно з 2016 роком і склала 77 ТН, тому доступність була розподілена таким чином: високодоступними були $65 \mathrm{TH}(84,41 \%)$, середньодоступними виявились 9 ТН (11,69\%), кількість низькодоступних ТН скоротилась до 3 (3,9\%). У 2018 році всі найменування були розподілені між двома категоріями: високодоступних ГЛЗ в кількості 71 ТН (89,87\%) та 
середньодоступних -8 ТН (10,13\%). У зв'язку з нестабільним курсом долару ціна на ЛІПРИМАР ${ }^{\circledR}$ знизилась, тому він перейшов 3 категорії низькодоступних до цілком середньодоступних за вартістю ГЛЗ для будь-якого громадянина.

На основі МНН розувастатину в 2015 році високодоступними були $34 \mathrm{TH}$ (61,82\%), середньодоступними - $20 \mathrm{TH}$ (36,36\%) та низькодоступними - лише $1 \mathrm{TH}-$ КРЕСТОР, AstraZeneca (Великобританія), табл. вкр./плів. обол. 40 мг блістер, № 28, на який прийшлось біля $2 \%$. У подальші роки розувастатин займав нішу високо- або середньодоступних гіполіпідемічних засобів. У 2016 році до високодоступних було віднесено $50 \mathrm{TH}(78,13 \%)$, відповідно, до середньодоступних $-21,87 \% \quad(14 \quad \mathrm{TH}) . \quad$ У 2017 році частка високодоступних досягла 90,54\% в кількості $67 \mathrm{TH}$, середньодоступні ж були представлені 7 ТН, що склало 9,46\%. В 2018 році відсоток високодоступних ГЛЗ зріс ще на 2\% і становив 92,21\% (71 ТН), число середньодоступних взагалі скоротилось до 6 ТН (7,79\%).

Найновіша на фармацевтичному ринку субстанція під МHН Пітавастатин протягом 2015-2018 років була представлена єдиною торговою назвою в широкому виборі дозувань - ЛІВАЗО囚. В процесі спостережень за соціально-економічною доступністю цього препарату були зафіксовані: в 2015 р. - по 1 ТН, представлені високо- та низькодоступними ЛЗ - ЛІВАЗО, Recordati Group (Італія), табл. вкр./плів. оболонкою 2 мг блістер, № 100 (по 16,67\% відповідно) та 4 ТН $(66,67 \%)$ - середньодоступними ГЛ3; у 2012-2017 рр. ситуація була схожою: співвідношення середньодоступних до низькодоступних розподілилось 80:20 (\%) - 4 ТН було віднесено до середньодоступних та $1 \mathrm{TH}$ до низькодоступних. У 2018 році змінилось тільки те, що єдина TH пітавастатину перейшла 3 категорії низькодоступних до високодоступних.

Проведений аналіз соціально-економічної доступності комбінованих гіполіпідемічних засобів групи статинів встановив, що протягом досліджуваного періоду не було виявлено препаратів, які входили до сегменту низькодоступних, окрім двох ТН препарату IHЕДЖІ® $з$ підгрупи С10B А02 Симвастатин + езетиміб, відсоток яких склав у 2015 році $50 \%$ (табл. 4).

Комбіновані ГЛЗ на основі МНН Аторвастатин + езетиміб у 2015 році 50 на 50\% були віднесені (по 1ТН) до високо- та середньодоступних Л3. У 2016-2017 р. середньодоступні повністю перейшли в категорію високодоступних ЛЗ.

У 2015 році препарати з ТН МНН Симвастатин + езетиміб по1 ТН були розподілені між високодоступними та середньодоступними 
категоріями. В 2016 р. всі ТН перейшли в сегмент середньодоступних, а в 2017 р. - до високодоступних. У 2018 - МНН зійшла 3 фармацевтичного ринку.

Найцікавішою за доступністю виявилась комбінація за МНH Аторвастатин + амлодипін: у 2015 р. високодоступні склали 77,78\% (7 $\mathrm{TH})$, середньодоступні - 22,22\% (2 TH); в 2016 р. частка високодоступних зменшилась до $71,43 \%$ (5 TH), проте середньодоступні зросли на 6\% (28,57\%) за рахунок тих же 2 TH.

Таблиця 4

Аналіз доступності комбінованих ЛЗ статинів за покакзником Ca.s

\begin{tabular}{|c|c|c|c|c|c|}
\hline \multirow{2}{*}{$\begin{array}{c}\text { АТС код, МНН } \\
\text { препарату }\end{array}$} & \multirow{2}{*}{ Категорія ЛЗ } & \multicolumn{4}{|c|}{$\begin{array}{c}\text { Кількість ТН ЛЗ у\% } \\
\text { (абсолютна величина) }\end{array}$} \\
\hline & & $2015 p$. & 2016 p. & 2017 p. & 2018 p. \\
\hline \multirow{3}{*}{$\begin{array}{c}\text { С10B А02 } \\
\text { Симвастатин та } \\
\text { езетиміб }\end{array}$} & Високодоступні & $\begin{array}{c}25 \\
(1 \mathrm{TH})\end{array}$ & - & $\begin{array}{c}100 \\
(3 \mathrm{TH})\end{array}$ & - \\
\hline & Середньодоступні & $\begin{array}{c}25 \\
(1 \mathrm{TH})\end{array}$ & $\begin{array}{c}100 \\
(3 \mathrm{TH})\end{array}$ & - & - \\
\hline & Низькодоступні & $\begin{array}{c}50 \\
(2 \mathrm{TH}) \\
\end{array}$ & - & - & - \\
\hline \multirow{3}{*}{$\begin{array}{c}\text { С10B А05 } \\
\text { Аторвастатин та } \\
\text { езетиміб }\end{array}$} & Високодоступні & $\begin{array}{c}50 \\
(1 \mathrm{TH}) \\
\end{array}$ & $\begin{array}{c}100 \\
(1 \mathrm{TH}) \\
\end{array}$ & $\begin{array}{c}100 \\
(2 \mathrm{TH}) \\
\end{array}$ & - \\
\hline & Середньодоступні & $50(1 \mathrm{TH})$ & - & - & - \\
\hline & Низькодоступні & - & - & - & - \\
\hline \multirow{3}{*}{$\begin{array}{c}\text { С10В Х03 } \\
\text { Аторвастатин та } \\
\text { амлодипін }\end{array}$} & Високодоступні & $\begin{array}{c}77,78 \\
(7 \mathrm{TH})\end{array}$ & $\begin{array}{c}71,43 \\
(5 \mathrm{TH})\end{array}$ & $\begin{array}{c}75 \\
(3 \mathrm{TH})\end{array}$ & $\begin{array}{c}66,67 \\
(2 \mathrm{TH})\end{array}$ \\
\hline & Середньодоступні & $\begin{array}{l}22,22 \\
(2 \mathrm{TH})\end{array}$ & $\begin{array}{c}28,57 \\
(2 \mathrm{TH})\end{array}$ & $\begin{array}{c}25 \\
(1 \mathrm{TH})\end{array}$ & $\begin{array}{c}33,33 \\
(1 \mathrm{TH})\end{array}$ \\
\hline & Низькодоступні & - & - & - & - \\
\hline \multirow{3}{*}{$\begin{array}{c}\text { С10В Х06 } \\
\text { Аторвастатин, } \\
\text { ацетилсаліцилова к-та } \\
\text { та раміприл }\end{array}$} & Високодоступні & - & - & $\begin{array}{c}100 \\
(3 \mathrm{TH}) \\
\end{array}$ & $\begin{array}{c}100 \\
(3 \mathrm{TH}) \\
\end{array}$ \\
\hline & Середньодоступні & - & - & - & - \\
\hline & Низькодоступні & - & - & - & $\begin{array}{c}100 \\
(4 \mathrm{TH})\end{array}$ \\
\hline \multirow{3}{*}{$\begin{array}{c}\text { С10B X10 } \\
\text { Розувастатин та } \\
\text { валсартан }\end{array}$} & Високодоступні & - & - & - & $\begin{array}{c}100 \\
(4 \mathrm{TH}) \\
\end{array}$ \\
\hline & Середньодоступні & - & - & - & - \\
\hline & Низькодоступні & - & - & - & - \\
\hline
\end{tabular}


У 2017 р. до високодоступних потрапили 3 ТН (75\%), і лише 1 ТН увійшла до складу середньодоступних ЛЗ. У 2018 році загальна кількість ТН була скорочена до 3, у зв'язку з чим були визначені 2 TH $(66,67 \%)$ серед високодоступних та $1 \mathrm{TH}$ серед середньодоступних КГЛЗ групи статинів.

Комбінація С10В Х06 Аторвастатин + ацетилсаліцилова кислота + раміприл прийшла на фармацевтичний ринок України лише в 2017 році, іï препарати в трьох різних дозуваннях під ТН ТРИНОМІЯ увійшли до сегменту високодоступних у обидва досліджувані роки.

\section{2. Дослідження об'ємів споживання гіполіпідемічних} лікарських засобів групи статинів за АTC/DDD-методологісю (ВОO3)

Проведені нами дослідження об'ємів споживання лікарських гіполіпідемічних засобів групи статинів показали, що протягом чотирьох досліджуваних років попит на статини то зростав, то зменшувався. Причому прослідковувалась тенденція до частого призначення лікарями саме препаратів з останніх поколінь випуску статинів, таких як розувастатин (пік споживання у 2018 р. склав 4,487 DDDs/1000 жит./день) та аторвастатин (у 2017 p. 3,599 DDDs/1000 жит./день). Вони стали лідерами монопрепаратів, що увійшли до складу істотно різних лікарських листів призначень 3 комбінованою терапією в лікуванні серцево-судинних патологій, цукрового діабету тощо. Перш за все їх споживча здатність була зумовлена високим профілем безпеки для різних категорій хворих на СС3 та доказаною ефективністю у відношенні лікування дисліпідемій різного генезу.

У міру того, як незначно призначався та споживався препарат флувастатину ЛЕСКОЛ® XL, Novartis Pharma (Швейцарія), табл. п/о 80 мг, № 28, його постачання на ринок України було припинене через неприбутковість та прихід на зміну нових, більш безпечних та ефективних ліпідознижуючих засобів, що за досить короткий термін часу могли швидко знизити та нормалізувати рівень ХС в крові. Останній раз він був помічений на фармацевтичному ринку України ще в 2015 році, його споживання було мізерним (0,000007 DDDs/1000 жит./день).

Стосовно МНН Пітавастатину можна сказати, що споживання було незначним через недостатні клінічні дані щодо ефективності препарату, отримані в результаті клінічних досліджень. Хоча ЛІВАЗО вже декілька років перебуває на фармацевтичному ринку України, однак ще не встиг себе зарекомендувати у вузьких медичних колах (рис. 1). 


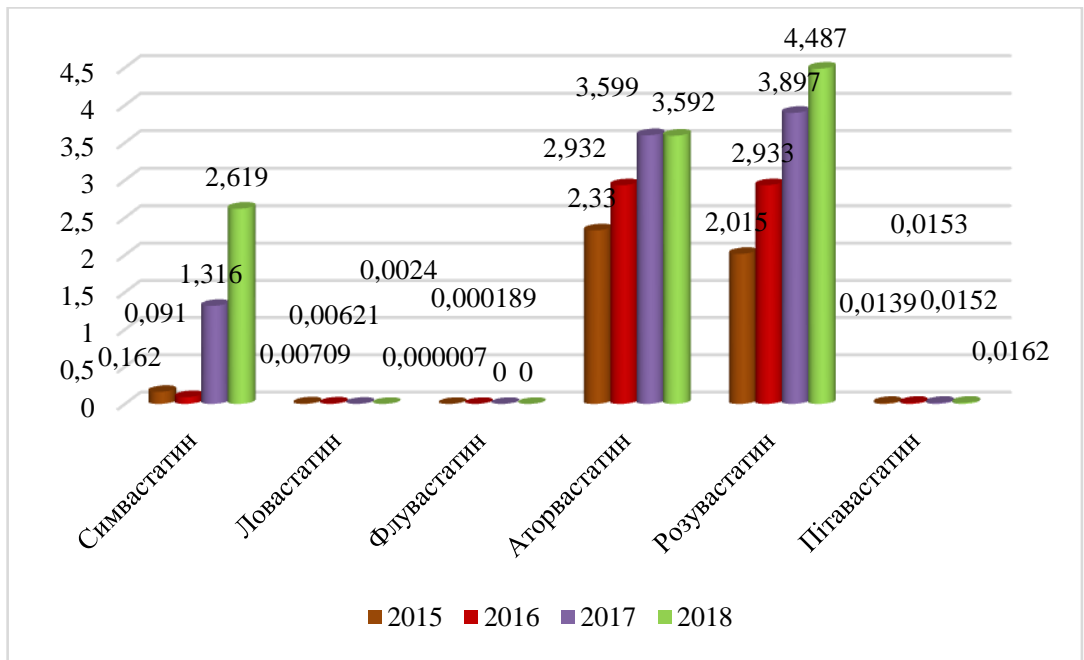

Рис. 1. Споживання гіполіпідемічних монопрепаратів групи статинів за роками

Питома вага комбінованих гіполіпідемічних засобів групи статинів в загальній структурі споживання інгібіторів ГМГ-КоА-редуктази була дуже незначною. Лікарські засоби комбінацій на основі МНН Симвастатин + езетиміб та Аторвастатин + езетиміб 3 кожним досліджуваним роком втрачали свої споживчі позиції через недостатній позитивний лікарський досвід щодо призначення такого поєднання активних речовин. У 2018 році вони остаточно пішли 3 фармацевтичного ринку України.

Споживання комбінації з МНН Аторвастатин + амлодипін всі чотири роки поспіль поступово йшло на спад, проте вона надійно закріпилась на фармацевтичному ринку України (для порівняння в 2015 р. - 0,0262 DDDs/1000 жит./день і в 2018 p. - 0,0144 DDDs/1000 жит./день) (рис. 2).

Серед найбільш споживаних протягом 2015-2018 pp. серед комбінацій групи статинів можна відмітити препарат ТРИНОМІЯ®, що складається с трьох активних лікарських молекул (пік споживання в 2018 p. - 0,061 DDDs/1000 жит./день).

Споживання комбінованого ГЛЗ під ТН ВАЛАРОКС (МНН Розувастатин - валсартан) від виробника KRKA становило 0,0021 DDDs/1000 жит./день.

Таким чином, серед ЛЗ Аторвастатину у мінімальній дозі найбільш дешевим та вигідним у відношенні економії коштів виявився АТОРВАСТАТИН 10 АНАНТА, Ananta Medicare (Індія), табл. вкр./плів. 
обол. 10 мг блістер, № 30 (вартість склала - 168,30 грн). Він займав 4-е місце по споживанню в 2018 році. Серед препаратів Розувастатину РОЗУВАСТАТИН-ТЕВА, Теva (Ізраїль), табл. вкр./плів. обол. 5 мг блістер, № 30 (вартість 117 грн). Він посів 2-е місце та поступився своєму конкуренту - ТН POКСЕРА®, KRKA d.d. Novo Mesto (Словенія), за об’ємом споживання.

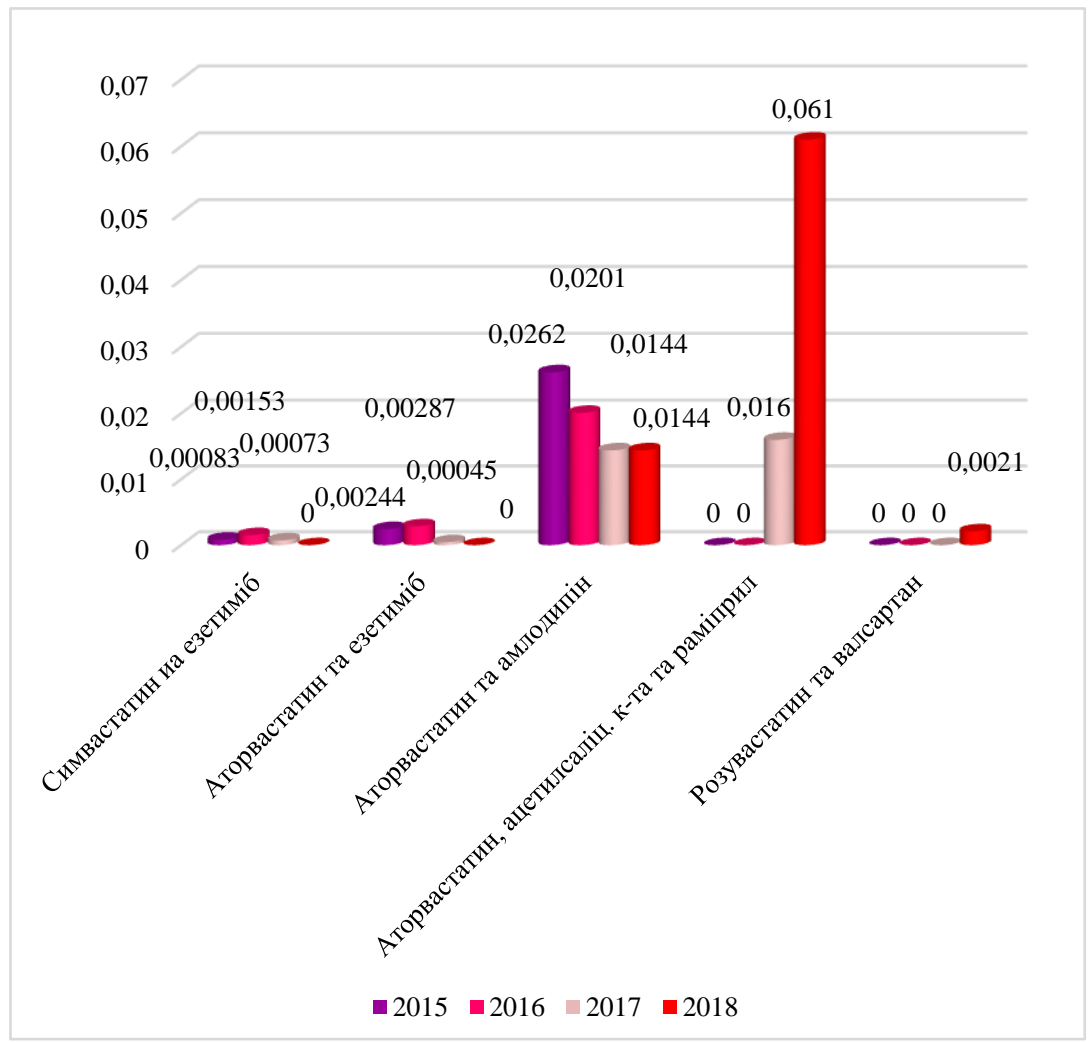

Рис. 2. Споживання комбінованих ГЛЗ групи статинів по роках

Виробників ГЛЗ МНН Аторвастатину та Розувастатину в максимальній дозі 40 мг на фармацевтичному ринку України виявилось значно менше, ніж відповідно в дозах 10 і 5 мг. Найменш економічно вигідним в максимальній дозі серед ТН Аторвастатину став ATOPEM 40, MSN Lab. (Індія), табл. вкр./плів. обол. 40 мг блістер, № 30 (ціна становила 422,10 грн). В топ-10 найуживаніших 
препаратів Аторвастатину він зайняв останній 10 щабель. Серед ГЛЗ МНH Розувастатину таким препаратом було обрано РОЗУВАСТАТИН ІС, ІнтерХім ТДВ ФФ (Україна, Одеса), табл. вкр./плів. обол. 40 мг блістер, № 30. Серед чотирьох місць - він виявився теж останнім.

\section{ВИСНОВКИ}

1. За аналізом асортименту монопрепаратів гіпохолестеринемічної дії встановлено, що на фармацевтичному ринку України протягом 2015-2018 років були присутні 6 МНH: Симвастатин (20-29 ТН), Ловастатин (1TH), Флувастатин (1 ТН тільки протягом 2015 р.), Аторвастатин (81-77 ТН), Розувастатин (55-77 ТН), Пітавастатин (5-6 ТН). ТН статинів були представлені переважно закордонними виробниками. Діапазон цін на ЛЗ включав як низькі, так і високі ціни, що дає можливості для вибору.

2. Асортимент комбінованих статинів на фармацевтичному ринку України представлений п'ятьма МНН: Симвастатин + езетиміб (3 ТН), Аторвастатин + езетиміб (2-0 TH), Аторвастатин + амлодипін (9-3 TH), Аторвастатин, ацетилсаліцилова кислота та раміприл (0-3 ТН), Розувастатин + валсартан (0-4). Кількість ТН на ринку склала 15 у 2015 році, далі зменшувалась. У 2018 році вона склала $10 \mathrm{TH}$.

3. Аналіз рівня доступності препаратів групи статинів за розрахунковим показником Ca.s показав, що усі МНH були представлені переважно високодоступними ЛЗ. У 2018 році поряд 3 високодоступними середньодоступними була незначна кількість ТН Аторвастатину (8TH), Розувастатину (6 TH), Пітавастатину (4 TH) та комбінованих препаратів: Аторвастатину + амлодипіну (1 $\mathrm{TH})$. У 2018 році на ринку також був присутній малодоступний комбінований препарат ТРИНОМІЯ (4 TH), який включає Аторвастатин + ацетилсаліцилову кислоту та раміприл. Рівень доступності ЛЗ групи статинів надає широкі можливості для вибору препаратів відповідно до матеріального стану пацієнта.

4. Найбільш споживаними в Україні протягом досліджуваного періоду були Симвастатин (2,6 DDDs/1000 жит./день у 2018 р.), Аторвастатин (3,6 DDDs/1000 жит./день), Розувастатин (4,5 DDDs/1000 жит./день) та комбінації: Аторвастатин + амлодипін (0,0144 DDDs/1000 жит./день) та ТРИНОМІЯ (0,061 DDDs/1000 жит./день у 2018 р.). Об'єми споживання статинів, які мають доказову базу клінічної ефективності при СС3, є недостатніми порівняно з кількістю хворих на СС3 в Україні. Так, Розувастатин приймали $0,45 \%$ населення України у 2018 році, Симвастатин $-0,26 \%$, а Аторвастатин $-0,36 \%$ населення у 2018 році. 


\section{АНОТАЦІЯ}

Дисліпідемія - один 3 основних критеріїв та причин розвитку атеросклерозу та ішемічної хвороби серця, що з часом призводить до інвалідизації та підвищує ризик ранньої смерті по всьому світі. Лікарські засоби (ЛЗ) групи статинів займають стабільне положення в кардіології і донині залишаються найбільш розповсюдженим класом препаратів, що застосовуються для лікування гіперхолестеринемії. Торгові найменування статинів представлені на фармацевтичному ринку України переважно закордонними виробниками. Діапазон цін на ЛЗ включає як низькі, так і високі ціни, що дає можливості для вибору. Аналіз рівня доступності ЛЗ групи статинів за розрахунковим показником Ca.s показав, що усі міжнародні непатентовані назви представлені переважно високодоступними ЛЗ, що надає широкі можливості для вибору препаратів відповідно до матеріального стану пацієнта. Найбільш споживаними в Україні протягом досліджуваного періоду були Симвастатин (2,6 DDDs/1000 жит./день у 2018 р.), Аторвастатин (3,6 DDDs/1000 жит./день), Розувастатин (4,5 DDDs/1000 жит./день) та комбінації: Аторвастатин + амлодипін (0,0144 DDDs/1000 жит./день) та ТРИНОМІЯ (0,061 DDDs/1000 жит./день у 2018 р.). Але за результатами досліджень об'єми споживання статинів, які мають доказову базу клінічної ефективності при серцево-судинних захворюваннях (СС3), є недостатніми порівняно з кількістю хворих на СС3 в Україні.

\section{ЛІТЕРАТУРА}

1. Европейский региональный комитет. 61-я сессия ВОЗ. Баку, 12-15 сент. 2011 г. План действий по Европейской стратегии профилактики и борьбы с неинфекционными заболеваниями, 2012-2016 гг. ВО3, 2011. С. 2-5.

2. Трагедія, якої можна уникнути: Подолання в Україні кризи здоров'я людини. Досвід Свропи. Світовий Банк. Київ, 2009. 72 с.

3. Бронцель М. Розувастатин на фоне других статинов. Польща: Клиника (кафедра) внутренних болезней и клинической фармакологии Медицинского университета в г. Лодзь, 2011. 7 с.

4. Серцево-судинні захворювання в Україні: прогнози - невтішні. Всеукрайнська медична газета “Ваше здоров'я”. 2015. URL: https://www.vz.kiev.ua/sercevo-sudinni-zaxvoryuvannya-v-ukrayiniprognozi-nevtishni/ (дата звернення: 20.01.2020). 
5. Мурашко Н.К., Матяш М.М., Парнікоза Т.П. та ін. Дисліпопротеінемії в неврологічній практиці : навч.-метод. рекомендації. Київ : Міністерство охорони здоров’я України, 2013.

6. Долженко М.М., Базілевич А.Я., Сімагіна Т.В. Застосування статинів у хворих на IXC. Київ : НМАПО ім.П.Л.Шупика спільно 3 ЛМДУ ім. Данила Галицького, 2011. 8 с.

7. Nissen S.E., Tuzcu E., Schoenhagen P. et al.; REVERSAL Investigators. Statin therapy, LDL cholesterol, C-reactive protein, and coronary artery disease. N. Engl. J. Med. 2005. Vol. 352. P. 29-38.

8. Banach M., Jankowski P., Jóźwiak J. et al. PoLA/CFPiP/PCS Guidelines for the Management of Dyslipidaemias for Family Physicians. Arch. Med. Sci. 2016. 13(1). P. 1-45.

9. Яковлєва Л.В., Бездітко Н.В., Герасимова О.О. Фармакоекономіка : навч. посібник для студентів вузів. Вінниця : Нова Книга, 2009. $208 \mathrm{c}$.

10. Сусеков А.В., Хохлова Н.В. ЛИПРИМАР $®$. Пятнадцать лет убедительных доказательств. Рациональная Фармакотерапия 6 Кардиологии. 2011. № 7. С. 231-240.

11. Гоголашвили Н. В. Аторвастатин - 20 лет в борьбе за жизнь. Российский кардиологический журнал. 2018. № 2. С. 134-149.

12. Аторвастатин: классические исследования и их современная интерпретация. Доказательная база аторвастатина для практического врача. Атмосфера. Новости кардиологии. 2015. № 2. С. 26-30.

13. Агеев Ф. Т. Аторвастатин: классические исследования и их современная интерпретация. Доказательная база аторвастатина для практического врача. Атмосфера. Новости кардиологии. 2015. № 2. C. $26-30$.

14. Пузік С.Г. Статини у профілактиці цереброваскулярних хвороб при арте-ріальній гіпертензії. У фокусі - аторвастатин. Семейная медиичин. 2015. № 3. С. 110-111.

15. Cholesterol Treatment Trialists (CTT) Collaboration. The effects of lowering LDL cholesterol with statin therapy in people at low risk of vascular disease: meta-analysis of individual data from 27 randomised trials. Lancet. 2012. Vol. 378.

16. Березин А.Е. Роль статинов в современной стратегии лечения кардиоваскулярных заболеваний: фокус на аторвастатин. Украӥнський медичний часопис. 2017. № 2. С. 89-93.

17. Reiner Z., Catapano A. L., De Backer G. et al. ESC/EAS Guidelines for the management of dyslipidaemias: the Task Force for the management of dyslipi-daemias of the European Society of Cardiology (ESC) and the 
European Athero-sclerosis Society (EAS). Eur Heart J. 2011. Vol. 32. P.1769-1818.

18. Rubba P., Marotta G., Gentile M. Efficacy and safety of rosuvastatin in the management of dyslipidemia. Vasc. Health Risk Manag. 2009. 5(1). P. 343-352.

19. Думенко Т.М., Парій В.Д., Яковлєва Л.В., Зіменковський А.Б. Вивчення доступності основних лікарських засобів в Україні: результати спільного проекту ВООЗ, НАI та МO3 Україні. Фармакоекономіка в Україні: стан та перспективи розвитку: матер. VI наук.-практ. конф. (Харків, 22 листопада 2013 р.). Харків : НФаУ, 2013. C. 180-281.

Information about authors: Shuliak L. M., on-the-job contract Graduate Student at the Department of

Pharmacoeconomics National University of Pharmacy 4, Valentynivska st., Kharkiv, 61000, Ukraine

Berdnyk O. H., Assistant Professor at the Department of Pharmacoeconomics National University of Pharmacy 4, Valentynivska st., Kharkiv, 61000, Ukraine 